\title{
ATTENDANCE AND INSTITUTIONAL FACILITIES OF LONG-TERM KIDNEY DONORS FOLLOW-UP
}

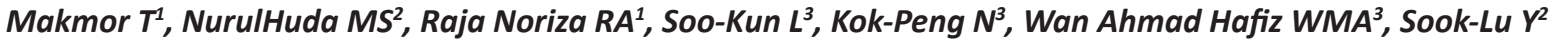 \\ 1 Department of Administrative Studies and Politics, Faculty of Economics and Administration, University of Malaya, \\ 50603 Kuala Lumpur, Malaysia. \\ 2 Department of Economics, Faculty of Economics and Administration, University of Malaya, Kuala Lumpur, Malaysia. \\ 3 Department of Medicine, Faculty of Medicine, University of Malaya, Kuala Lumpur, Malaysia.
}

\author{
Correspondence: \\ Makmor Tumin \\ Department of Administrative Studies and Politics, \\ Faculty of Economics and Administration, \\ University of Malaya, 50603 Kuala Lumpur \\ Email:makmor@um.edu.my \\ Phone: +603-79673690 \\ Fax: $+603-79673719$
}

\begin{abstract}
Introduction:

Living donation is an important source for organs transplantation in Malaysia. This study aims to investigate the Malaysian living donors' follow-up attendance, their preferences on medical-institutional facilities, and the financial circumstances pertaining to the follow-up costs
\end{abstract}

\section{Materials and Methods:}

Primary data were collected through a survey of 80 living donors who made their donation at the University of Malaya Medical Center (UMMC) between 1991 and 2012.

Results:

Out total of 178 donors, only 111 were reachable and 80 of them participated in the survey (72\%). The findings revealed that most of the donors (71.2\%) attend the follow-up regularly. Nevertheless, donors seem to neglect the importance of follow-up as they consider themselves healthy $(28.9 \%)$ or consider the follow-up as being troublesome (28.9\%). Most donors (67.5\%) are not in favour of being treated as patients, but prefer to be monitored under donor registry (88.8\%) and getting their health service in special clinics for donors (80\%). The majority of the donors fund the follow-up costs themselves (32.4\%), while $25 \%$ of the donors' follow-up costs were funded by family members. Among those donors without income and those of low-income $(84.8 \%$ of respondents), $60.3 \%$ believe that the follow-up costs should be borne by the government.

\section{Conclusions:}

Based on the findings, it is therefore suggested that the government provides all living donors with proper free health service through donor registry and donor clinics. Adequate care has to be given to the donors to pre-empt any unforeseen health complications due to the organ donation surgical procedures.

Keywords: Living donors, follow-up, kidney donation, Malaysia

\section{Introduction}

Thousands of patients around the world are dying every year due to kidney failure. The advancement in transplantation has given the world a new source of treatment for end-stage kidney failure (1). Nevertheless, the shortage of donated organ has severely impeded the number of transplantation in many countries, and Malaysia is no exception (2). For instance, on average, there had been only about 100 kidney transplantations performed yearly in Malaysia (3). 
Kidneys can be donated by any living or deceased individual, yet the importance of living donation varies from one country to another. In countries with successful organ donation experience, such as Spain, Croatia and Malta, deceased donation forms the main pool of organ donation (4). This finding makes the source from living donation of lower importance (3). In Spain, for instance, the rates of organ donation were 35.12 per million population (PMP) for deceased and 8.59 PMP for living donation (3).

In Malaysia, living donation is of huge importance as a source of organ transplantation for two reasons. The first reason is the huge gap between the demand for organs and the low donation rate. In 2012, there were 28,590 dialysis patients, and although about half of them were registered on the waiting list for transplantation, there were only 94 transplantations, involving living and deceased donors, performed in that year (5). The second reason is that living donation outnumbers deceased donation by more than $300 \%$, although both have been recording very low rates. In 2013, it was recorded that there was 1.87 PMP living donation compared to only 0.5 PMP for deceased donation (3).

Malaysia adheres to the Informed Consent system, in which those who are willing to donate their organs after death must register officially during their life time (6, 7). As per the official records, there were no "unrelated living donation" in the last two decades (8). In Malaysia, past experiences indicated that living donations has, thus far, been only within the family. This means living donors have only donated organs to genetically or emotionally connected recipients (8). The situation has remained the same as in the yesteryears even after the government has introduced clear guidelines and procedures for "unrelated living donations" in 2011 (9). To improve the rate of living donation, donors must be assured that their quality of life (QoL) after donation would not be compromised (10). They should also be helped to avoid any financial hardship as a consequence of donating their organ. The fear of medical or financial risks of organ donation could gravely lessen donation rates (11). A study on 133 potential donors revealed that $24 \%$ of them had not donated their organs due to their fear of facing financial hardship after donation (12). In another study, financial hardship was reported by about $23 \%$ of living donors after donating their organs (13).

One of the imperative factors to maintain donors' standard QoL is that they should attend post-donation follow-up sessions to monitor their health status (14). The importance of follow-up is stressed in the world health organization (WHO) principles of organ donation which states that "live donations are acceptable when the donor's informed and voluntary consent is obtained, when professional care of donors is ensured and follow-up is well organized" (15).

The Malaysian transplant policy requires living donors to go for follow-up (Clause 3.4), and that their welfare will be taken care of by the government (Clause 2.5) (16). However, the follow-up was left at donors' discretion and there is no institutionalized living donor registry to monitor their follow-up activities. In 2012, free secondary and tertiary medical facilities were only granted to donors who donated after 2012 (17). This means that the burden of follow-up costs is not borne by the government for those who donated before 2012 .

Previous studies showed that living kidney donors do not suffer from any reduction in their $\operatorname{QoL}(18,19)$, or an increase in mortality rate (20-22), compared to non-donors who are in the control group. However, the literature shows that a small proportion of living donors in the United States and adhere to their long-term follow-up $(19,23)$. In the case of Malaysia, an earlier study of 80 living kidney donors revealed that they have better QoL compared to 80 healthy individuals (24). However, to the best of our knowledge, there have been no studies which explore the follow-up status and wellbeing of the Malaysian living donors. Thus, this study aims to investigate the Malaysian living donors' follow-up attendance, their preferences on medicalinstitutional facilities, and the financial circumstances pertaining to the follow-up costs.

\section{Methods}

To achieve the objectives of the study, we examine the perspectives of a sample of living donors who donated their organs at the University Malaya Medical Centre (UMMC) between 1991 and 2012. The time frame of between 1991 and 2012 indicates that the donors involved in this study are those who did not have access to free follow-up medical facilities. Out of 178 donors, only 111 were reachable and 80 of them participated in the survey (72\%). From the 31 reachable non-respondent donors, 11 stated that they were not free, 10 refused to participate, 5 were abroad, 2 were having their follow-ups in other hospitals, 2 had passed away and 1 was chronically ill.

A pilot-tested questionnaire was developed and two enumerators (one from UMMC and the other, an independent third party) were tasked to assist the donors to fill out the questionnaire.

First, donors were asked to indicate the frequency of attending the follow up sessions. They were given three options to choose from: 'regular', 'non-regular', and 'never' attend. Next, all respondents were asked to choose two reasons (out of six) as to the causes of their not attending the follow up sessions. The decision to give the option to choose two out of six reasons was based on the request by respondents captured during the pilot study. We understood from the pilot study that we may encounter low response rate. Therefore, the following reasons were developed based on hypothetical assumptions by the donors who attended regular and non-regular follow-up sessions. The donors were asked about their possible reasons if they have chosen not to attend the followup sessions. The six reasons were developed based on literatures and discussions with nephrologists, surgeons, and psychiatrists from UMMC. The reasons were as follows: (1) I am just as healthy as anybody I know; (2) the doctor did not advise me to do so; (3) I do not want to take the 
trouble; (4) I do not want to be used as a research object; (5) I am having financial problems; and (6) Others.

Next, respondents without income and those who are in the low-income category (RM0-RM1000 per month) were asked to indicate the party paying for their followup costs and also the party they believe should be the payer. The follow-up costs here include consultation fees, blood tests, drug supplements, and miscellaneous. The payer and should be payer list was as follows: (1) Myself; (2) The kidney recipient; (3) My family members; (4) Charitable organization(s); (5) Private organization(s); (6) The government; and (7) Others.

Finally, we explored the respondents' views regarding their medical-institutional facilities. Respondents were asked whether they would like: (1) to be dealt with as patients, (2) to be under the supervision of 'donor clinic', (3) to be registered and monitored by living donor registry, or (4) to have an independent donor advocate. For each item, respondents were given three options 'Yes', 'No', and 'Undecided'. With respect to the organ donation-related institutions, the donors were told clearly about the donor clinic, donor registry and independent donor advocate.

This research was approved by the Medical Ethics Committee, University Malaya Medical Centre (MEC Ref. No : 932.23 ) on $19^{\text {th }}$ July, 2012.

\section{Results}

Table 1 reports the respondent's social and economic background. Among the 80 donors, 57 (71.3\%) were regularly attending their follow-up, 18 (22.5\%) were nonregularly attending, and $5(6.3 \%)$ had never attended the follow-up.

Table 1. Respondents' background $(n=80)$

\begin{tabular}{|l|l|c|}
\hline \multirow{4}{*}{ Gender } & Female & $64 \%$ \\
\cline { 2 - 3 } & Male & $36 \%$ \\
\hline \multirow{4}{*}{ Marital status } & Married & $80 \%$ \\
\cline { 2 - 3 } & Single & $16 \%$ \\
\cline { 2 - 3 } & Divorced & $4 \%$ \\
\hline \multirow{5}{*}{ Income per month } & Below 40 & $18.75 \%$. \\
\cline { 2 - 3 } & 41-55 & $40 \%$ \\
\cline { 2 - 3 } & Above 56 & $41.25 \%$ \\
\hline & No income & $33.80 \%$ \\
\cline { 2 - 3 } & Below RM3000 & $51 \%$ \\
\cline { 2 - 3 } & RM3000 - RM4000 & $11.25 \%$ \\
\cline { 2 - 3 } & Above RM4000 & $3.75 \%$ \\
\hline
\end{tabular}

As shown in Table 2, about 30\% of respondents consider themselves healthy and thus, consider themselves not in need of attending the follow-up. The second top cited reason for not attending the follow-up sessions was ' don't want to take the trouble' (28.1\%); while the other reasons captured lower attention. Under 'Others' option, all respondents explained that they could not come for the follow-up because they were busy with their work.
Chi-square tests showed no differences in the reasons given among the three categories of respondents ( $P>0.78$ ). The reasons mentioned by the respondents are both hypothetical (for the regular and non-regular attendees) and actual (for those who never attended). 
Table 2: Reasons for not attending follow-up sessions.

\begin{tabular}{|c|c|c|c|c|}
\hline Reasons & $\begin{array}{l}\text { Regular } \\
(n=57)\end{array}$ & $\begin{array}{l}\text { Non-regular } \\
\quad(n=18)\end{array}$ & $\begin{array}{l}\text { Never } \\
(n=5)\end{array}$ & $\begin{array}{l}\text { Total } \\
(n=80)\end{array}$ \\
\hline 1. I am just as healthy as anybody I know & $\begin{array}{c}33 \\
(28.9 \%)\end{array}$ & $\begin{array}{c}10 \\
(27.8 \%)\end{array}$ & $\begin{array}{c}4 \\
(40.0 \%)\end{array}$ & $\begin{array}{c}47 \\
(29.4 \%)\end{array}$ \\
\hline 2. The doctor did not advise me to do so & $\begin{array}{c}17 \\
(14.9 \%)\end{array}$ & $\begin{array}{c}7 \\
(19.4 \%)\end{array}$ & $\begin{array}{c}2 \\
(20.0 \%)\end{array}$ & $\begin{array}{c}26 \\
(16.3 \%)\end{array}$ \\
\hline 3. I do not want to take the trouble & $\begin{array}{c}33 \\
(28.9 \%) \\
\end{array}$ & $\begin{array}{c}10 \\
(27.8 \%)\end{array}$ & $\begin{array}{c}2 \\
(20.0 \%)\end{array}$ & $\begin{array}{c}45 \\
(28.1 \%)\end{array}$ \\
\hline 4. I do not want to be used as a research object & $\begin{array}{c}4 \\
(3.5 \%) \\
\end{array}$ & $\begin{array}{c}1 \\
(2.8 \%) \\
\end{array}$ & $\begin{array}{c}0 \\
(0.0 \%)\end{array}$ & $\begin{array}{c}\mathbf{5} \\
(3.1 \%)\end{array}$ \\
\hline 5. I am having financial problems & $\begin{array}{c}14 \\
(12.3 \%)\end{array}$ & $\begin{array}{c}5 \\
(13.9 \%)\end{array}$ & $\begin{array}{c}0 \\
(0.0 \%)\end{array}$ & $\begin{array}{c}19 \\
(11.9 \%)\end{array}$ \\
\hline 6. Others & $\begin{array}{c}13 \\
(11.4 \%)\end{array}$ & $\begin{array}{c}3 \\
(8.3 \%)\end{array}$ & $\begin{array}{c}2 \\
(20.0 \%)\end{array}$ & $\begin{array}{c}18 \\
(11.3 \%)\end{array}$ \\
\hline Total & $\begin{array}{c}114 \\
(100.0 \%)\end{array}$ & $\begin{array}{c}36 \\
(100.0 \%)\end{array}$ & $\begin{array}{c}10 \\
(100.0 \%)\end{array}$ & $\begin{array}{c}160 \\
(100.0 \%)\end{array}$ \\
\hline
\end{tabular}

The results revealed that the majority of donors bore the costs of the follow-up sessions themselves (32.4\%), while $25.0 \%$ were funded by their family members. The government funded the follow-up of only $17.6 \%$ of the donors, while the bulk (60.3\%) of donors believe that the government should be the payer (Table 3 ).
The chi-square test revealed significant difference between the respondents' actual payer and 'should-be' payer, according to the donors' perception $(P<0.01)$.

Table 3: Payer and 'should be' payer of follow-up costs for low and no-income group donors

\begin{tabular}{|c|c|c|c|}
\hline Payer & $\begin{array}{l}\text { Actual payer } \\
(n=68)\end{array}$ & $\begin{array}{c}\text { 'Should-be' payer } \\
(n=68)\end{array}$ & $\begin{array}{c}\text { Chi-square test } \\
\text { P-value }\end{array}$ \\
\hline Myself & $\begin{array}{c}22 \\
(32.4 \%)\end{array}$ & $\begin{array}{c}10 \\
(14.7 \%)\end{array}$ & 0.03 \\
\hline The kidney recipient & $\begin{array}{c}13 \\
(19.1 \%) \\
\end{array}$ & $\begin{array}{c}4 \\
(5.9 \%) \\
\end{array}$ & 0.03 \\
\hline My family members & $\begin{array}{c}17 \\
(25.0 \%)\end{array}$ & $\begin{array}{c}10 \\
(14.7 \%)\end{array}$ & n.s* \\
\hline Charitable organization(s) & $\begin{array}{c}1 \\
(1.5 \%) \\
\end{array}$ & $\begin{array}{c}1 \\
(1.5 \%) \\
\end{array}$ & n.s \\
\hline Private organization(s) & $\begin{array}{c}1 \\
(1.5 \%) \\
\end{array}$ & $\begin{array}{c}0 \\
(0.0 \%) \\
\end{array}$ & n.s \\
\hline The government & $\begin{array}{c}12 \\
(17.6 \%)\end{array}$ & $\begin{array}{c}41 \\
(60.3 \%)\end{array}$ & 0.00 \\
\hline Others & $\begin{array}{c}2 \\
(2.9 \%)\end{array}$ & $\begin{array}{c}2 \\
(2.9 \%)\end{array}$ & n.s \\
\hline
\end{tabular}

*n.s: not significant

As illustrated in Table 4, more than two thirds of the respondents refused to be treated as patients. On the other hand, the bulk of respondents (more than $80 \%$ ), showed an interest in having special donor registry and donor clinics to manage and monitor their health status after donation. However, only $40 \%$ of donors said 'yes' for having independent donor advocate. 
Table 4: Donors' views on treatment, facilities and transplant institutions

\begin{tabular}{|c|c|c|c|}
\hline Views & Yes & No & Undecided \\
\hline I should be considered/treated as a patient too & $\begin{array}{c}15 \\
(18.8 \%)\end{array}$ & $\begin{array}{c}54 \\
(67.5 \%)\end{array}$ & $\begin{array}{c}11 \\
(13.8 \%)\end{array}$ \\
\hline The government should set-up clinics for donors & $\begin{array}{c}64 \\
(80.0 \%)\end{array}$ & $\begin{array}{c}3 \\
(3.8 \%)\end{array}$ & $\begin{array}{c}13 \\
(16.3 \%)\end{array}$ \\
\hline $\begin{array}{l}\text { All donors should be systematically registered and monitored } \\
\text { (living donors registry) }\end{array}$ & $\begin{array}{c}71 \\
(88.8 \%)\end{array}$ & $\begin{array}{c}3 \\
(3.8 \%)\end{array}$ & $\begin{array}{l}6 \\
(7.5 \%)\end{array}$ \\
\hline $\begin{array}{l}\text { I need to get advice from an independent individual who } \\
\text { can represent and voice my interest (independent donor } \\
\text { advocate) }\end{array}$ & $\begin{array}{c}32 \\
(40.0 \%)\end{array}$ & $\begin{array}{c}23 \\
(28.8 \%)\end{array}$ & $\begin{array}{c}25 \\
(31.3 \%)\end{array}$ \\
\hline
\end{tabular}

\section{Discussion}

The results showed that Malaysians who are living donors have a high frequency of follow-up attendance, in which about $71 \%$ of respondents were regularly attending the follow-up. However, we cannot build a strong conclusion that the Malaysian living donors have higher follow-up commitment than their counterparts in other countries, given that only 80 donors out of 178 participated in this study.

Although the level of attendance among the respondents appears high, the majority of them seem to be unaware about the importance of the follow-up. This finding is shown by statistics, in which $29 \%$ of respondents stated that they might not need to pursue the follow-up sessions because they are as healthy as the new-donors. What confirmed the last mentioned idea is that another $29 \%$ of respondents considered the follow-up attendance as 'troublesome'. Another $11 \%$ believed that their work could be more important than the follow-up. Given these facts, we believe that there should be serious and urgent awareness campaigns targeting the living donors so as to educate them on the importance of the follow-up for their post-donation health status.

Although only $12 \%$ of respondents cited financial costs as the reason/could-be-reason of not attending the followup, the majority of the low and no-income respondents were funding their own follow-up costs. Nonetheless, the majority of donors felt that the financial burden of the follow-up was to be the duty of the government. The results showed that there is incongruity between expectation and reality. In the light of these results, omitting 2012 living donors from receiving free follow-up service might leave serious implications on the donor's life.

Therefore, we suggest that the government should bear the financial responsibility, and include all living donors as eligible to receive free follow-up service. The government should also take the initiative to establish special clinics for living donors and monitor donors' health under an official donor registry.
The donors should be duly informed about the existence and the roles of the independent donor advocate, so that the donors know about the source or entity to address if any possible grievances or problems arise in the future.

\section{Conclusion}

Even though majority studies have indicated that living donors are just as safe as other normal individuals both in morbidity and quality of life, the need to attend follow-up sessions should be emphasized by the government so as to avoid any unwarranted health issues. This also indirectly shows that the government takes care of the well-being of the donors.

Providing proper health care to the living organ donors is expected to increase the number of living donations. Prospective donors would more likely feel that their health status will be monitored and that they would not face any financial hardship after the donation. These efforts would have the potential to encourage all prospective donors to donate. Consequently, increasing the number of living donors could relieve a severe shortage of the pool of human organs in Malaysia.

A flexible system to accommodate the donors' availability in attending follow-up sessions should be introduced. Furthermore, a mandatory national living organ donors' registry ought to be established to keep track of the list of individuals who have donated organs. The role of the independent donor advocate should be structured holistically to ensure good service to the donors. Having the presence of the independent donor advocates alone is not good enough; their existence should be made known widely and they should be easily accessible.

\section{Competing Interest}

It is hereby declared that there is no conflict of interest pertaining to this paper. 


\section{References}

1. Dangoor JY, Hakim DN, Singh RP, Hakim NS. Transplantation : A Brief History. Exp Clin Transplant. 2014. doi:10.6002/ect.2014.0258.

2. Tumin M, Tafran K, Mutalib MATA, et al. Demographic and socioeconomic factors influencing public attitudes toward a presumed consent system for organ donation without and with a priority allocation scheme. Med (United States). 2015;94(42):e1713. doi:10.1097/MD.0000000000001713.

3. IRODaT. International registry of organ donation and transplantation. http://www.irodat.org/. Published 2014. Accessed October 28, 2014.

4. Shepherd L, O'Carroll RE, Ferguson E. An international comparison of deceased and living organ donation/ transplant rates in opt-in and opt-out systems: a panel study. BMC Med. 2014;12(1):1-14. doi:10.1186/ s12916-014-0131-4.

5. Lim YN, Ong LM, Goh BL (eds). 20th Report of the Malaysian Dialysis and Transplant Registry. Kuala Lumpur: National Renal Registry, Malaysian Society of Nephrology. 2012.

6. Rosenblum AM, Horvat LD, Siminoff L a., Prakash V, Beitel J, Garg AX. The authority of next-of-kin in explicit and presumed consent systems for deceased organ donation: An analysis of 54 nations. Nephrol Dial Transplant. 2012;27(6):2533-2546. doi:10.1093/ ndt/gfr619.

7. HTA. Human Tissues Act 1974. Putrajaya: The Commissioner of Law Revision, Malaysia; 2006.

8. Hooi LS, Mansor LY. Ninth Report of the National Transplant Registry 2012. Kuala Lumpur; 2015.

9. Ministry of Health Malaysia (MoH). Unrelated Living Organ Donation: Policy And Procedures. Putrajaya: Ministry of Health Malaysia (MOH); 2011. http:// www.moh.gov.my/images/gallery/orga/Unrelated_ Living.pdf.

10. Johnson EM, Najarian JS, Matas AJ. Living kidney donation: donor risks and quality of life. Clin Transplant. January 1997:231-240. http://www. ncbi.nlm.nih.gov/pubmed/9919408. Accessed May 16, 2016.

11. Klarenbach S, Garg AX, Vlaicu S. Living organ donors face financial barriers: a national reimbursement policy is needed. CMAJ 2006; 174:797-8.

12. Knotts RS, Finn WF, Armstrong T. Psychosocial factors impacting patients, donors, and nondonors involved in renal transplant evaluation. Perspect 1996; 15:1123.

13. Schover LR, Streem SB, Boparai N, Duriak K, Novick AC. The psychosocial impact of donating a kidney: long-term follow-up from a urology based center. $J$ Urol 1997; 157:1596-601.

14. Tumin M, Mohd Satar N, Raja Ariffin RN, et al. The importance of long-term follow-up visits for kidnay donors. JUMMEC. 2015;18(2):1-6.

15. Word Health Organization (WHO). Guiding principles on human cell, tissue and organ transplantation. As endorsed by the sixty-third World Health Assembly in May 2010, in Resolution WHA63.22.

16. National Organ, Tissue, and Cell Transplantation Policy. Ministry of Health Malaysia: Kuala Lumpur. 2007: 5-6.

17. Ministry of Health Malaysia: Circular (64) in. KKM58/900/69 Vol. 7 dated 21 November 2012.

18. Ibrahim HN, Foley R, Tan L, Rogers T, Bailey RF, Guo $\mathrm{H}$, et al. Long-term consequences of kidney donation. N Engl J Med. 2009; 360(5):459-69.

19. Glotzer OS, Singh TP, Gallichio MH, Conti D J, Siparsky NF. Long-term quality of life after living kidney donation. Transplant Proc. 2013; 45(9):3225-8.

20. Segev DL, Muzaale AD, Caffo BS, Mehta SH, Singer AL, Taranto SE, et al. Perioperative mortality and longterm survival following live kidney donation. JAMA. 2010; 303(10); 959-66.

21. Okamoto M, Akioka K, Nobori S, Ushigome H, Kozaki $\mathrm{K}$, Kaihara $\mathrm{S}$, et al. Short- and long-term donor outcomes after kidney donation: analysis of 601 cases over a 35-year period at Japanese single center. Transplantation. 2009; 87(3): 419-23.

22. Matas AJ, Bartlett ST, Leichtman AB, Delmonico FL. Morbidity and mortality after living kidney donation, 1999-2001: survey of United States transplant centers. Am J Transplant. 2003; 3(7):830-4.

23. Mandelbrot DA, Pavlakis M, Karp SJ, Johnson SR, Hanto DW, Rodrigue JR. Practices and barriers in long-term living kidney donor follow-up: a survey of US transplant centers. Transplantation. 2009; 88(7):855-60.

24. Tumin M, Abdul Talib @ Abdul Mutalib M, Mohd Satar N, Abdullah N, Chong CS, Ng KP, Lim SK. A comparison of donor and control group quality of life. Ann Transplant 2013; 19:112-8. 